COST AND PRICE MOVEMENTS IN BUSINESS CYCLE THEORIES AND EXPERIENCE:

CAUSES AND EFFECTS OF OBSERVED CHANGES

Victor Zarnowitz

Working Paper No. 3132

NATIONAL BUREAU OF ECONOMIC RESEARCH

1050 Massachusetts Avenue

Cambridge, MA 02138

October 1989

This paper is part of NBER's research program in Economic Fluctuations. Any opinions expressed are those of the author not those of the National Bureau of Economic Research. 
NBER Working Paper \#3132

October 1989

\title{
COST AND PRICE MOVEMENTS IN BUSINESS CYCLE THEORIES AND EXPERIENCE: CAUSES AND EFFECTS OF OBSERVED CHANGES
}

\begin{abstract}
This paper is a sequel to Working Paper No. 3131, "Hypotheses of Sticky Wages and Prices". My first objective is to re-examine the historical record of prices and wages. What changes in their behavior are indicated by the data and how can they be explained? Next, the models that imply that price flexibility may be destabilizing are identified and assessed. This requires in particular an analysis of the role of changes in interest rates and price expectations.

Money wages and prices in general had a predominantly procyclical pattern of movement before World War II, at least during the major fluctuations, but no declines in the more recent business contractions. Real wages never conformed closely to business cycles but most of their weak reactions were procyclical.

Depending on the underlying condition and sources of the shifts in the economy, the departures from flexibility may or may not be destabilizing. The main contrast, though, is between the stabilizing potential of flexible relative prices and the detabilizing potential of major general price movements.

Major deflations of the past had strong and adverse expectational and distributional effects. So had the recent inflation as it accelerated and grew increasingly volatile. But moderate fluctuations in the price level or the rate of inflation are not necessarily detrimental to the growth in real economic activity.
\end{abstract}

Victor Zarnowitz 
I. Historical Evidence and Current Theories

\section{Nominal and Real Wage- in Business Cycles}

Data on the historical behavior of wage earnings and rates have been assembled and explored in several pioneering studies. I compiled measures of aspects of cyclical movements in these time series for the prewar, interwar, and postwar periods, and present them in Table 1.

The average annual money earnings from wages declined in about half of the business contractions of 1860-1914, but in all of those of 1920-38, according to the data compiled in Phelps Brown 1968 (Table 1, lines 1-2). In contrast, they kept rising through the period 1945-60, which witnessed four moderate or mild recessions (line 3). Data for 1889-1914 from Rees 1961 show that peaks and troughs in annual earnings matched nearly two thirds of the like business cycle turns of the period, those in hourly earnings fewer than half (lines 7 and 8 ). But hourly earnings score high on cyclical conformity in the interwar period, according to both the annual series from Rees 1960 and the monthly series from Creamer 1956 (Lines 9 and 11). The same applies to an index of money wage rates presented in Creamer 1950 (line 12). 
The conclusion is that most of the major business downturns and some of the minor ones have historically been associated with declines in the nominal wage earnings. For example, the annual Rees series on hourly earnings shows downward movements in 1893-95, 1896-98, 1903-04, 1907-08, and 1913-14; also, in 1920-22, 1924-25, 1929-33, and 1937-39 (see Rees 1961, pp. 33-34, and Rees 1960, pp. 2-3). Earlier data in Douglas 1930 are broadly consistent with these results. The monthly series declined strongly but with long lags in response to the depressions of 1920-21 and 1929-33, very mildly and sluggishly during and/or after the other business contractions of the interwar period (Creamer 1950 and 1956 , ch. 5). The comprehensive study by Phelps Brown, which goes back to 1860 and also covers France, Germany, Sweden, and the United Kingdom, supplies much additional evidence that money wages basically followed a procyclical pattern of movement in the eight decades preceding World War II, though skipping many smaller fluctuations.

However, it is clear from all available data and generally accepted that no cyclical declines at all occurred in any of the comprehensive money-wage indicators for the United States after 1945. Such long and sustained expansions in wage rates and incomes, hitherto unprecedented, prevailed concurrently in other major industrialized and market-oriented countries as well, reflecting both the generally rising prosperity and inflation of the postwar era.

The real wage series used in Table 1 are estimated by dividing the moneywage series by cost-of-living or consumer price indexes. Before 1914, more business cycle turns were matched by like turns in deflated annual and hourly earnings than in the coresponding nominal data, but the real series had more irregular timing and smaller amplitudes (cf. lines 1 and 4, and lines 8 and 10). In 1920-38, deflated annual earnings moved in sympathy with all major 
business contractions and recoveries but skipped the smaller cycles, which the money earnings did not ( $\mathrm{c}$. lines 2 and 5).

In 1945-60, the nominal series did not decline at all, while the real series declined only between 1945 and 1947, lagging behind the business contraction of 1944-46, which marked the reconversion from the war to the peacetime economy ( $c f$. lines 3 and 6 ). The currently available quarterly BLS data on the real hourly compensation of production or nonsupervisory workers on private nonagricultural payrolls provide strong, consistent evidence that these real wages did in fact keep rising throughout the 1947-60 period with its four recessions ( 1 ine 13). However, the same series shows much less growth and more cyclicality in recent times; it flattened in 1969-70 and declined mildly but with considerable persistence in 1973-74, 1978-81, and 1983-84, matching five of the eight business cycle turns of the period since 1961 (line 14).

Several inferences can be made from this simple analysis supported by a detailed inspection of the underlying data. First, real wages do not conform closely to business cycles but they do fluctuate in a predominantly procyclical fashion. Before 1914 and between the world wars, these movements tended to be somewhat less frequent and smaller than those of nominal wages, but the situation was reversed in the recent era of persistent price and wage inflation. No consistent patterns of leads or lags emerge from the mix of measures in Table 1, columns 4-8; however, the crudeness of the available historical data leaves the resuits on cyclical timing much less definite than one would wish them to be. 1

\section{Measurement Problems and Recent Studies}

To answer the question whether real wages had declines corresponding to 
the contractions as dated by the NBER, no detrending or differencing operations are needed. More complicated questions about the responsiveness of real wages to changes in employment require more subtle econometric and timeseries analytic techniques. Studies of this problem, which are generally restricted by the data to very recent and short segments of time, produced mixed and partly contradictory characterizations of real wage behavior. One difficulty here is that the composition of the work force varies, in part systematically, over the business cycle. Expansions generate more overtime income. Those who change jobs and new entrants have more procyclical and on the average lower wages than those who stay on the same job. Hence the net effect of aggregation is a countercycical bias, as shown in Bils 1985 .

Another important point to make is that real wages as discussed so far (and as computed in most empirical studies) are money wages deflated by the consumer price index, not by the price index of the current output of labor. The wage in terms of the consumables is of prime interest to workers, while the wage in terms of the products of work (product wage rate) is of prime interest to firms and the one that is appropriate to use for comparisons and tests involving the productivity of labor. Producer prices tend to vary more than consumer prices; if money wages were less flexible than PPI but more flexible than CPI, then the PPI-deflated real wages could turn out to be countercyclical or acyclical at the sane time that the CPI-deflated real wages were procyclical.

Bernanke and Powell 1986 find that real wages (CPI-deflated) were weakly procyclical, lagged output significantly in the prewar (1923-39) period, and more nearly coincided with output or even led it in some industries in the postwar (1954-82) period. Product wages (PPI-deflated) led more often, particularly in the recent era, and had larger and more erratic variations and 
some countercyclical tendencies. Both real and product wages were more serially persistent and less cyclically variable in the postwar than in the prewar period. ${ }^{2}$

Money wages show long and pronounced upward trends, so an analysis of the cyclical behavior of their first differences or deviations from trend must complement the level analysis. Looking at differences between rates of change, last year of expansion minus contraction, in the average hourly compensation in manufacturing, Sachs 1980 finds that they were negative in 13 of 17 business cycles betwen 1890 and 1975.3 Thus a deceleration of growth or disinflation in wages marked most of the business cycle downturns. Absolute declines in wages, however, occurred only on five of these occasions, all of them before World War II. According to these annual data, wage inflation actually accelerated in the recessions of 1969-70 and 1973-75.

Sachs also presents similar measures for the wholesale price index. His figures show that prices slowed more than wages in nine episodes, less in six, the same in two. This suggests that the product wage rate had no clear and consistent pattern of behavior, though it may have moved more of ten counterthan procyclically. Both wages and producer prices reacted on the average more to strong than moderate contractions, and more to moderate than mild contractions (see ibid., Tables 1 and 2 and text).

In sum, the study of historical data makes it clear that the inflexibility of money wages in not a universal law (as some of the recent literature would suggest) but is essentially a phenomenon of the post-World War II period. Much the same statement can be made about the stickiness of the price level in the face of aggregate demand changes, as demonstrated below. 


\section{Trends and Cycles in Producer and Consumer Price Indexes}

The main fact about the recent evolution of both wages and prices is that they ceased declining during the postwar business recessions, i.e., disinflation replaced deflation. The evidence on this point, is substantial and uncontradicted (Cagan 1975, 1979; Zarnowitz and Moore 1986; Zarnowitz 1989). Important spatial as well as temporal differences exist in the degree of stickiness of money wages and prices (Gordon 1983).

Table 2 shows that for the first 150 years of United States history the annual all-commodity wholesale price index (WPI) had a strong tendency to decline during business contractions (lines 1-6, column 10). This era can be divided into three periods marked by inflation (associated to a large extent with wars) alternating with three periods of deflation (columns 1-5, 8). The cyclical conformity of prices, as indicated by the percentage of business cycle peaks and troughs matched by like turns in the WPI, was considerable throughout and, interestingly, on average higher in the deflationary than in the inflationary periods (columns 6-7). When the trend in WPI was up, the index rose strongly in expansions and fell weakly in contractions; when the trend was down, the movements in the index were likewise procyclical, only tilted in the opposite direction (columns 8-10). Also, in the former periods the year-to-year increases in the index were more frequent than the decreases, while in the latter periods the opposite was the case (1ines 1-6, columns 34). For the era 1789-1932 as a whole, the decreases were nearly as frequent as increases.

The record for the consumer price index (CPI) is somewhat shorter but it too leaves no doubt about the basically procyclical behavior of prices between 1820 and 1932, even on the annual basis (lines 13-17). Again, the distinction between the inflationary and deflationary periods shows up clearly in the 
data. The frequency of decreases is somewhat less here than for WPI.

In the two decades after the "great contraction" of the early 1930s ( a very turbulent age of initial depression, World War II, and the Korean War), prices embarked on a long upward trend but they still declined in two of the three business contractions, the excepticn being the recession of 1945 that marked the economy's reconversion to peace time (Iines 7 and 18). However, in the three following decades the annual price indexes ceased altogether declining in response to recessions (after a single early episode of a slight decrease in WPI; of. Iines 8 and 19). Indeed, in 1952-82 for the first time both WPI and CPI rose on average more in the years of contraction than in those of expansion.

Even if many individual prices often remained the same over many months each, one would not expect such "no change" sequences to be sufficiently long, widespread, and synchronized to result in high frequency of zero year-to-year change in aggregate price indexes. In fact, no change accounts for 7-10\% of the observations in the annual WPI for 1814-64, and for 8-19\% of the observations in the annual CPI for the five subperiods of 1820-1932 (column 5). ${ }^{4}$

Monthly data contain more noise than the annual data but also more information, particularly on persistence and timing. In 1953-64, 35\% of the monthly changes in WPI were effectively zero; in 1964-76, 19\%; and in 1976-88, only $5 \% .5$ of course, as inflation intensified, there was a steady $r$ ise in the share of index increases (from 39\% of the time in 1953-64 to $74 \%$ in 1976-88), but the share of decreases exceeded 20\% in both 1953-64 and 1976-88 (it fell to $12 \%$ in 1964-76). However, these decreases were sporadic and did not amount to cyclical movements matching the business contractions after the mid1950s. Indeed, in the 1970s the largest rises in the WPI occurred during the 
recessions associated with the huge oil price shocks. (These and other recessions also caused some reductions in the rate of inflation but only with considerable lags.) The monthly CPI series shows an even greater preponderance of increases and generally higher inflation rates (cf. lines 912 and $20-23$ ).

\section{Trends in Unionization and Competition}

As we have seen, a high degree of temporal stability or inertia of wages and prices is often treated in the literature as a stylized fact of business cycles in market economies. There is no dearth of models that purport to account for this behavior but it is difficult to discriminate among them without either questioning their premises or broadening the range of phenomena they address. ${ }^{6}$ Taking the latter route, it should be helpful to ask of any relevant theory that it help explain why the resistance of wage and price levels to decline in business contractions increased in the period after World War II (not simply why the rigidities exist, for the evidence is that they are by no means universal).

Several of the hypotheses in question assume deviations from the competitive model in form of negotiated wages and price setting by firms. Did the degree of monopoly-- of market power of labor and business-- $r$ ise historically and produce reductions in wage and price flexibility? There is no clear and established answer to this broad question, and I can only touch upon the controversial matters involved here. But the issue cannot be avoided. My reading of the literature and evidence suggests that (a) unionization probably did contribute to the changed behavior of wages after the Great Contraction of 1929-33 and in the first two or three post-World II decades; (b) it is at least doubtful that a general increase in the degree of 
monopoly occurred, although this probably does not rule out the possibility that noncompetitive practices or conduct became more common.

(a) Unionization. There is a considerable consensus that the smaller cyclical variability and greater persistence of wages in the postdepression era are attributable to a significant extent to the rise of labor unions. The sensitivity of wages to cyclical changes in unemployment and related labor market conditions is smaller in the union than in the nonunion sector so that recessions generally increase the pay advantage of union workers (Rees 1973, chs. 10 and 16; D.J.B. Mitchell 1980, chs. 4 and 6). The rapid growth in unionization, from $6 \%$ of the labor force in 1933 to $27 \%$ in 1953, was naturally associated with large increases in the role, scale, and costs of collective bargaining. Impasses and strikes can be particularly costly to both parties in a dispute, so that long, often three-year, union contracts became common in the postwar period.

However, union membership in the United States fell $a x$ share of the total labor force since the mid-1950s and in absolute numb : since the mid1970s, despite a rise in the public sector. Employer resistance to unions stiffened as growth rates of output and labor productivity declined and competition intensified internationally (Freeman 1988; Reder 1988). Wages and benefits negotiated by major unions grew in 1968-79 at annual rates averaging nearly $10 \%$ for the first year and $7.5 \%$ for the second and thind contract years, according to the BLS data. During the recession year 1982 , these rates fell rapidly to about $3 \%$ over the $l$ ife of the contracts, and they remained there (occasionally even lower) in the ensuing expansion. Correspondingly, real average hourly earnings and compensation of production workers on private payrolls grew but weakly and discontinuously in the 1980s. This remarkable development surely reflected the loss of economic and political power of the 
unions but also other, partly related and temporary factors: disinflation, import penetration, and declines or slow growth of some of the older domestic industries. 7

(b) Concentration and market power. Formidable conceptual, measurement, and aggregation problems beset all attempts to estimate the extent (and, even more, the trend) of competition vs. monopoly in the economy. Most of the evidence comes from concentration ratios, particularly for manufacturing, but the relationship between these measures and the degree of monopoly depends on the size of the domestic market, the importance of foreign competition, the availability of substitutes, and the extent of collusion. Views on the issue have long ranged from the popular but undocumented belief that competition is steadily and perhaps strongly declining to the more cautious and supportable suggestion that there is much stability over time in the aggregate concentration, and no clear unidirectional trend. ${ }^{8}$ The share of the 100 largest corporations in total manufacturing assets moved up from $34 \%$ to $42 \%$ in $1927-$ 33, down to $38 \%$ in 1941 , up from $37 \%$ to $46 \%$ in 1947-57 and up again from near 45\% to 48\% in 1966-71 (Scherer 1980, Figure 3.1, p. 48). There is much agreement that close approaches to both pure competition and pure monopoly are rare, but some authors stress the prevalence of broadly defined or "workable" competition, others that of monopolistic competition and oligopoly (ef. Nutter 1951, p. 44, and Scherer 1980, p. 67).

If it were well established that market power increased and competitive price taking gave way to price setting under conditions of imperfect competition, models that rely on the latter should have a better chance to explain the apparent rise in price inertia. (As shown in Carlton 1986, the average length of spells of price rigidity is an increasing function of industry concentration.) But there is no convineing evidence that greater 
monopoly power is what actually distinguishes that last forty years from the earlier era. Large corporations setting prices have been around for a long time. The increasing globalization of markets is an important postwar trend that presumably had the net effect of raising the levels of competition and the importance of changes in relative prices and wages.

\section{How to Explain the Observed Changes}

The expected consequence of labor's experience in the depressed 1930 s would be an increase in workers' aversion to the risk of both income and (probably even more) job losses. This should have given rise to greater demand for insurance of employment as well as wages. But labor contracts commonly specify basic income to be paid for work and fringe benefits; they do not assure tenure. In the postwar era, the cyclical variability of money wages practically vanished, but unemployment continued to have large cyclical swings and even had a definite upward trend. It is difficult to see how the implicit contract theory can explain these phenomena.

The idea that above-equilibrium rea: wages are required to attract productive and loyal workers would seem to apply better to prosperous than depressed times, to large established companies with internal labor markets than small firms with uncertain prospects, to high-paying career jobs than low-paying menial jobs. It is possible that the applicability of the efficiency wage theory increased during the postwar era, which was one of long phases of expansion, with strong growth of career employment in the corporate sector and elsewhere (government, professions). But this is presently only a vague speculation; in fact, there is as yet little tested knowledge to bear on the validity of models of this type. 
Much the same applies to the menu cost theory of pricing. The overall costs of changing prices not having been measured, we simply do not know what they are, how they vary across time and space, and how they compare with the costs of changing quantities (of output, inventories, backlogs). We do know that stable prices reduce communication costs to sellers and shopping costs to buyers, which is conducive to long-term associations between the transacting parties. Perhaps the importance of such associations in the economy increased in recent times but, again, the facts of the matter are yet to be established.

It follows that the recent theories of real and nominal rigidities fail to explain well the distinct change in the cyclical behavior of wages and prices that appears in the recent postwar data compared with the long earlier record. More generally, the currently popular models assume that business cycles result from the way the economy reacts to stochastic disturbances treated as exogenous. When the shocks are from a single source, frequent, and random, the fluctuations will have common properties and be fairly regular. Such models are not well equipped to account for any systematic changes or trends in the way the economy moves over time. Important examples are offered by the contemporary market-clearing equilibrium theories of business cycles, which on reflection are found to be particularly ahistorical.

A comprehensive theory that would explain the reasons for both the persistence and the evolution of cycles remains a major unaccomplished task. But when the observed changes that are likely to have contributed to the relative stabilization of the economy in recent times are taken as given, it can be seen that they are probably also responsible in part for the reduction in the cyclicality of wages and prices. Thus, services are cyclically less sensitive than goods with regard to not only output and employment but also wages and prices (see part I, table 2 above and Moore 1983, ch, 12). Hence 
the large $r$ ise in the relative importance of services will have had the effect of making the overall cost and price indexes more sticky. As the needs and preferences of consumers and producers grew more diversified and technologies to satisfy them were being developed, the share of output made to order may well have increased, too. 9 If so, the result would be a greater role for delivery lag adjustments and a smaller one for price adjustments (perhaps also some reductions in the overall levels of manufacturers' finished inventories and short-term demand uncertainty).

The persistence of inflation in the postwar era should have rationally promoted indexation of incomes and increased the frequency of individual prices rises; that is, it probably worked to reduce nominal wage and price rigidities on the upward side but may have raised them on the downward side. But all this was apparently consistent with much inertia in the micro price data.

The effects of government policies were mixed, partly stabilizing and positive, partly interfering with relative price adjustments and negative (consider, e.g., the price supports for farm products). To the extent that the experience of greater macroeconomic stability generates expectations of more of the same, the probability that business recessions will remain relatively short and mild increases. Since buyers see less reason to reduce spending, sellers see less reason to reduce prices of inputs and outputs. But the optimism can be reversed by shocks or side developments such as the accelerated inflation in the 1970s, and both positive and negative expectations can be temporarily self-fulfilling.

In sum, it is not coincidental that the cyclicality of wages and prices declined during the last half century even while business cycles moderated and inflation prevailed. But it is still possible that more flexibility would 
have helped. Unit labor costs in manufacturing, which used to fall during business contractions, decreased less and with lags (mainly during recoveries) in 1948-65. Between 1966 and 1980 ULC experienced only retardations as money wages rose strongly despite the adverse supply shocks and a decline in the growth rates of gross productivity of labor (whose procyclical and leading behavior pattern, however, remained unchanged). So new concern was expressed about the stickiness of wages, which was linked by some authors to the stagflation of the 1970s (Moore and Cullity 1983; Haberler 1988).

Yet the classical view that more flexibility is always desirable is not universally accepted. In what follows an opposite hypothesis will be considered.

\section{Price Expectations and Interest Rates}

\section{Expectational and Distributional Effects of Deflations and Inflations}

A macroeconomic model represents flexible prices by a steep, and sticky prices by a flat, aggregate supply (AS) curve. If the short-term fluctuations in aggregate demand (AD) are treated as given, the flatter $A S$ is, the more real activity will fluctuate. Hence, by this simple argument price flexibility is necessarily stabilizing.

It is possible, however, that the variation of $A D$ itself is not independent, but rather an increasing function, of the flexibility of wages and prices in general. For this to be so, it is necessary that the expected rate of price change ( $p^{e}$ ) has a strong positive effect on $A D$, while the actual price level ( $P$ ) has a weak negative effect (Tobin 1975). If $P$ declines in a recession, this raises the real values of the money stock and net wealth of the public and hence acts to reverse the decline. ${ }^{10}$ But if at the same time 
pe turns negative, i.e., a deflation is widely expected, then this would tend to depress $A D$ by causing postponement of purchases. In an early statement, Patinkin 1948 contrasted the roles of $P$ and $p^{e}$ under the headings of static and dynamic analysis, respectively, and noted that the expectational effect, though presumably temporary, could well prove the stronger in the short-run.

A similar distinction between level and expected change effects applies to nominal wages. A reduction in the current relative to the prospective future wage level would mean lower production costs now and hence encourage employment and investment. However, the anticipation that wage rates generally will continue to decline would depress expected incomes, demand, and profitability and result in deferment of consumption and investment. Other possible consequences of wage cuts include, on the positive side, lower interest rates (through reduced money demand), higher net exports (through reduced costs and greater competitiveness in an open economy), and possibly more business optimism. On the negative side, redistributional effects detrimental to workers and debtors would be likely to diminish aggregate demand .

A point-counter-point discussion of these arguments led Keynes (1936, ch. 19) to the conclusion that, on balance, there is little to recommend gradual reductions in money wages as a cure against depression. If prices fell in step with wages, no advantage of lower real costs would accrue to the employers; if prices were destabilized ard fell more, conditions would deteriorate further. Decentralized wage bargaining can alter the relative money wages, not the overall level of real wages.

Moreover, it has long been recognized that, when debt contracts are set in nominal terms, deflation worsens the financial position of debtors by raising the real value of their liabilities (Eisher 1933; Keynes 1936; Hart 
1938; Minsky 1975, 1977). Such contracts certainly exist on a large scale in the United States and many other countries. True, the assets of creditors increase in real value at the same time, but the two effects need not and probably do not offset each other completely (Tobin 1975, 1980). Debtors spend more than creditors relative to their respective incomes and wealth (this is why the former borrow and the latter lend in the first place). Debtors who face increasing threats of insolvency are apt to curtail their spending sharply, and those who actually go bankrupt cause directly losses to creditors. In this way, deflation can aggravate a business contraction by contributing to the shrinkage of private demand - both consumption and investment. This effect should be the stronger, the larger are the nominal debt payment commitments and the farther prices fall below the levels anticipated when the debts were incurred. Thus, following a large accumulation of debts in a period of economic expansion, a downturn accompanied by deflation can greatly increase the incidence of defaults and failures among banks, businesses, farms, and homeowners. In the 1930s, the results probably included a sharp $r$ ise in the real costs of financial intermediation, impeding the functioning of credit markets and depressing macroeconomic activity (Bernanke 1981, 1983). Simulations in Caskey and Eazzari 1987 suggest that a large real-debt effect can make greater wage-andprice flexibility seriously destabilizing. 11

In the absence of a general deflation, relative price movements combined with nominal debt contracting can seriously hurt some industries, occupations, or sectors, but these are partial difficulties that normally remain contained. The case in point is the experience of debt-burdened farmers after the 1981-82 recession when prices of their products and land stopped rising or fell. (The industry and regional troubles associated with the oil price decline of 1986 constitute another example.) 
Just as unanticipated deflation shifts income from debtors to creditors, unanticipated inflation does the opposite. The associated wealth redistribution effects are probably substantial, but individual losses and gains largely offset each other so that the costs to society vary and are difficult to determine (Fischer and Modigliani 1978). If money wages are sticky, unexpected price level rises would reduce real wages and increase output. If there are no nominal rigidities but people misperceive the absolute for relative price rises, then unanticipated inflation would also increase output by raising labor supply. Analogousiy, surprise deflation has negative effects on real aggregate economic activity in both those Keynesian theories that have nominal contracts with limited or delayed wage adjustments and those neoclassical theories that assume flexible wages and prices but also incomplete information.

Large inflations or deflations of monetary origin are likely to obstruct rather than promote the flexibility of relative prices that is instrumental to the proper functioning of the market economy. Actual wage and price flexibility being always limited, deflations often aggravated the severe depressions of the past and inflations often contributed stresses and imbalances to expansions. The long and uneven inflation of the 1970s, in particular, evoked much common disconten: and led to some destabilizing policy actions.

History suggests that what matters is not so much the direction but rather the size and variability of the general price movement. Large and volatile short-term changes, up as well as down, are difficult to predict, generate uncertainty, and affect adverse-y real economic activity. Evidence based mainly on data for the late 1960s and the 1970s, when both inflation and unemployment rates were $r$ ising and inflation was increasingly variable, is 
consistent with this hypothesis (see, a.o., M. Friedman 1977; Makin 1982; Zarnowitz and Lambros 1987). So is, a fortiori, the evidence for the short but severe depression of 1920 and the first half of 1921, which was preceded by a large wartime and postwar inflation and accompanied for a year (beginning in mid-1920) by the most conspicuously rapid deflation on record for the U.S. (Eriedman and Schwartz 1963, ch. 5). On the other hand, one can find examples of moderate deflation or inflation coexisting with either high or low real growth rates. 12

\section{Models with Potentially Destabilizing Price and Interest Expectations}

The prevailing view attributes the fact that no major depressions and deflations occurred since the 1930 s to expansionary policies, smaller disturbances, institutional improvements, and gains in confidence. Thus, Taylor (1986a) credits these factors, especially smaller nominal GNP shocks, with the improvement in economic stability; this, he holds, occurred despite the greater rigidity of wages and prices. Monetary authorities react to rising inflation with tighter policies; this depresses output growth, which in time reduces inflation. The result has been smaller variances of the growth rates of output and prices but also greater persistence (serial correlation) of the fluctuations in both variables.

In contrast, DeLong and Sumers argue that at least some of the postwar moderation of the cycle is due precisely to the money wages and prices having become more sticky and persistent. They assume that the short-run nominal interest rate $i$ enters the $L M$ equation, and the real rate $r^{e}=i-p^{e}$ enters the IS equation (1986b, pp. 1034-35). IS and LM together determine AD, while Taylor's model of overlapping wage contracts is used on the supply side. There is a serially correlated demand shift term but no wage or price shock. 
The model implies that increased price flexibility is destabilizing at the margin over a considerable range of assumed parameter values. Again the reason is that output reacts more elastically to $p^{e}$ than to $P$, but the channel is $r^{e}$. If people expect disinflation or deflation, i.e., $p^{e}$ falls or becomes negative, then so long as $i$ does not adjust fully, $r^{e}$ will increase, lowering real investment and output. Correspondingly, when $p^{e}$ rises, $r^{e}$ will fall, which raises economic activity. Hence, more price variability causes more output instability.

However, as shown by Driskill and Sheffrin 1986, increasing price flexibility is stabilizing at the margin in systems where fluctuations are driven by supply shocks (as in contract models with shocks to nominal wages, see Taylor 1979, 1980). Hence greater price flexibility may simultaneously increase the output variance generated by demand shocks and reduce the output variance generated by supply shocks. The former effect will prevail over the latter in a model in which demand shocks are serially correlated while supply shocks are not (DeLong and Summers 1986b, pp. 1039-40). But the postwar era witnessed some large supply (or price adjustment) shocks of considerable persistence. It is clear that generally the results will depend on the mix and correlations of the demand and supply shifts.

Further, the assumption of a policy rule that links money supply to the interest rate leaves no room for any stabilizing role of monetary policy. Yet monetary growth was much less volatile in the post-World War II era than in the earlier periods and was, moreover, free of the previously experienced phases of negative values (see Zarnowitz 1989, Chart 3 and Tables 1 and 3 ). Policy may deserve some credit for this development, even if it is to a large extent endogenous (cf. H. Grossman 1986). The stabilizing potential of flexible prices would be much enhanced under conditions of stable growth of 
nominal demand in the will-0'-the-wisp model with optimal monetary policy (S. King 1988).

Still another problem is that investment may depend more on long-term than on short-term interest rates. Using long rates would narrow, though not necessarily remove, the range of destabilizing price flexibility (DeLong and Summers 1986b, pp. 1041-42).

In basic analytical terms, the short-run relationship between $i$ and $p$ (two endogenous, simultaneously determined variables) is unstable because it depends on the nature of the shifts in, or disturbances to, the system as a whole. This argument is sufficient to show that there is no simple and definite way to relate changes in $r^{e}$ to economic fluctuations.

Still, even a highly stylized atzempt at some quantifiable linkage should be worthwhile. In times when persistent inflation is recognized and expected to continue undiminished, the simple price adjustment equation

(5) $p=p_{-1}+b\left(Q-Q^{*}\right) / Q^{*}$, may not be a bad assumption. ${ }^{13}$ (Here $Q$ is actual and $Q^{*}$ is potential output; subscripts t are omitted.) A dynamic version of the demand function for money is approximately

(6) $m-p=k q-h \Delta i / i$, where $\Delta \mathrm{i}=\mathrm{i}-\mathrm{i}_{-1}$. Following the derivation in Baily 1978, pp. 42-45, consider an $A D$ shock that raises $Q$ above $Q^{*}$ by a fraction $Q$ as money and prices incease at the equilibrium rate $\bar{m}=\bar{p}$. Then, from (5),

(7) $\mathrm{p}=\overline{\mathrm{p}}+\mathrm{bq}$,

and (6) and (7) imply that

(8) $\Delta i / i=q\left(\frac{k+b}{h}\right)$.

Suppose that the deviation of $p$ from $\bar{p}$ in (7) is anticipated. Then, 
differencing the definitional equation $r^{e}=i-p^{e}$ and using (8) results in (9) $\Delta r r^{e}=\Delta i-b q$.

And combining ( 8 ) and (9) gives

(10) $\Delta r^{e}=q\left(\frac{i k+i b-b h}{h}\right)$.

When equation $(10)$ is solved for aiternative values of the parameters (Table 3), several relationships emerge. First, when inflation accelerates strongly in response to excess demand as measured by the GNP gap, i.e., b in (5) is large, $\Delta r^{e}$ falls, given the values of $i, k$, and $h$. So in this sense greater price flexibility can be destablizing in the short run (see part $A$ of the table). Second, given $i$ and $b, \Delta r{ }^{e}$ increases for higher values of the interest elasticity of the demand for money $k$ and decreases for higher vaiues of the interest elasticity of the demand for money $h$. When $h$ is as large as 0.5 , changes in $r^{e}$ are destabilizing ( $\mathrm{cr}$. Table 3, part B). Third, at values of $k, b$, and $h$ that seem reasonable $\left(0.7,0.2\right.$, and 0.2 , respectiveiy), $\Delta r^{e}$ is negative at relatively low values of the nominal interest rate $i$ (part c). The meaning of this is not clear at all. The presence of $i$ in (10) makes $\Delta r$ dependent on money growth even in the long run, but the proper focus of this analysis is certainly on moderate short-run movements.

The examples suggest that $r^{e}$ will change only by small amounts in response to a rise or fall of one percent in total output: for plausible parameter readings, perhaps at most by 30 or 40 basis points, most iikeiy less. ${ }^{14}$ This seems to be a sensible result that is consistent with much that is known about the behavior of interest rates and price expectations.

On the other hand, the DeLong-Summers hypothesis implies that changes in $r^{e}$ strongly influence aggregate economic activity, presumably through their effects on real private investment broadly defined (I). Since these changes are generally small, this requires a high elasticity of I with respect to 
$r^{e}$. Although such a major role for $r^{e}$ is consistent with theory, it has not found much systematic support in the data. Most tests show relatively weak effects of cost of capital or the real interest rate on business and household real capital outlays, and some show no significant net effects at all. ${ }^{15}$

\section{Interest and Inflation in History}

What the expected inflation rates and real interest rates are at any time is always very uncertain, as indicated by the diversity of estimates of $p^{e}$ obtained from different sources or by different methods (surveys of consumers and forecasters; inferences from financial and commodity market data; statistical implementation of the rational expectations model). Historically, the response of nominal interest rates to movements in the rate of price change has been quite varied and mostly weak.

Before World War II, inflation and deflation alternated in peacetime expansions and contractions, allowing for longer trends; short-term interest rates moved procyclically, like wholesale prices, but with longer and irregular lags, and long-term rates had much smaller fluctuations and weaker conformity to business cycles (Zarnowitz and Moore 1986, pp. 553-565). Short rates moved in broad sympathy to the very large waves of inflation and deflation during and after World War $I$ and to deflation during the slump of 1929-33, but even then their adjustment was lagged and incomplete. The ex post, observable real rate, $r=i-p$, was much of the time dominated by short erratic variations; it shows little association with output and other cyclical variables but a strong negative correlation with inflation (Mishkin 1981). Large changes in $r$ are observed but sporadically, mostly as a passive result of strong and persistent price movements, as in 1920-21 and 1929-33 (DeLong and Summers 1986a, pp. 710-711). 
The evidence is consistent with the hypothesis that most of the time people viewed the price movement as transitory and limited, so that their expectations smoothed out much of it. Hence, the changes in $p^{e}$ tended to be small and not persistent so that the $r^{e}$ and : values were on the whole close. ${ }^{16}$

A markedly tighter relation between $i$ and $p$ arises only in the second half of the 1960s and through the 1970s, a period during which the persistence of inflation must have become public knowledge. This is shown clearly by the graphs and correlations in. Friedman and Schwartz 1982, pp. 527-546 (see also Summers 1963, pp. 216-225.) The real rate rose from negative to high positive values during the great inflation of this period, which probably reflected largely the expectational adjustments of $i$ to $p$. It should be noted, however, that the relationship weakened again during the following years of disinflation: r remained high in 1981-85 as $i$ declined much less than $p$ did.

The DeLong-Summers hypothesis relies on the "nonadjustment" of nominal interest rates, i.e., it requires that $i$ respond only sluggishly and incompletely to changes in $p^{e}$. If the response is sufficiently strong, the change in $r^{e}$ will be too small to have much of a destabilizing effect. Thus, the increase in the promptness and size of interest adjustments during the "great inflation" segment of the post-World War II period should have reduced the applicability of the hypothesis. And, according to the theoretical argument already noted, the same applies to the effects of the supply shocks, which also occurred in the 1970s.

To conclude, the hypothesis that stickier wages and prices had a moderating influence on postwar business cycles remains open. It was neither shown to draw much support from the data nor invalidated. The problem is no longer the theoretical possibility of price flexibility being destabilizing, 
which clearly exists; it is the historical importance of such a condition. This can be resolved only by more and better empirical research. 17

A more limited hypothesis, which I think is favored by some general considerations and historical evidence, is that only large changes in $p^{e}$ and $r^{2}$ associated with major deflations, inflations, and disinflations have much destabilizing potential; small and moderate changes, which are far more common, matter little. But, as noted earlier, large movements in prices are usually volatile as well, and their unanticipated components are at least as likely to have adverse real effects (the rise in inflation uncertainty during the 1970 s is an important case in point).

\section{II . Concluding Observations}

This paper completes a two-part attempt to produce an integrated overview of an important subject: the properties and role of cost and price movements in past and recent business cycles. To summarize a few of its main results:

Comprehensive indexes of money wages and prices had a tendency to move procyclically before World War II, at least during the major economic fluctuations, but they show no sustained declines in the postwar business contractions. Real wages are acyclical or weakly procyclical.

The role of sticky wages and prices in business cycles depends on the prevailing conditions and sources of instability. The departures from flexibility need not be always destabilizing; indeed, protracted and anticipated wage declines can aggravate demand contractions. But large wage increases can also worsen a stagflation. The strong hypothesis that the increased rigidities actually reduced the instability throughout the postwar era does not score convincingly against aiternatives. The counterarguments 
draw support from the increased responsiveness of interest rates to changes in expected inflation and the importance of supply shocks in the 1970s. Relative price flexibility should be generally stabilizing; it is the volatility of changes in the overall price level that can be troublesome.

The destabilizing potential of general price movements is probably nonlinear: great for large and rapid, negligible for small and slow changes. Major deflations of the past had demonstrably strong and adverse expectational and distributional effects. As the recent inflation accelerated, it grew increasingly volatile, generated much uncertainty and popular discontent, and led to policy interventions that had disturbing consequences of their own. Moderate fluctuations in the price level or the rate of inflation have not been inconsistent with reasonably steady growth in real activity. 
Footnotes

${ }^{1}$ Annual data for 1920-38 show only coincidences (Table 4, 1 ine 5) but this does not preclude short leads and lags. Such data are insufficiently sensitive to short and mild business contractions; unfortunately, quarterly or monthly data of adequate coverage and quality are available only for short recent periods. It should be noted that the leads and lags in columns 7-8 of the table are all stated in fractions of a year for comparability, even though the entries in lines 11-12 are based on monthly and those in lines 13-14 on quarterly data (to get the leads in months and quarters, multiply these figures by 12 and 4 , respectively).

2 Bernanke and Powell report getting stronger indications of cyclicality from frequency domain than time domain analysis (applied to monthly data for several major industries as well as all-manufacturing aggregates). They attribute Geary and Kennan 1982 result that product wages are not significantly associated with employment in the United States and other OECD countries to the noisiness of these relationships in the time domain ( $p .617$ ).

See also Tsiang 1947 for an early analysis of the U.S. interwar data that suggests a similar distinction between the behavior of real wages and that of product wages.

${ }^{3}$ The Great Depression and World War II years are excluded from these measures. Prices and wages fell in 1929-33 but rose strongly through the rest of the 1930s despite high unemployment. This is widely viewed as anomalous and attributable to special factors, namely the New Deal legislation, the support and growth of unions, and later the wartime administrative controls.

${ }^{4}$ It should be noted that these early index series carry no decimals.

5 The monthly series for both WPI and CPI carry one decimal each.

${ }^{6}$ The models usually make assumptions that are as arbitrary and strong as dictated by analytical convenience, but they would presumably apply in the first instance to the recent (postwar) aggregate U.S. data.

${ }^{7}$ At the same time, the civilian unemployment rate in the U.s. fell from $10.8 \%$ to $5.0 \%$ between December 1982 and March 1989. In contrast, unemployment rose and remained high in Europe where linions are generally much more powerful, despite the concurrent business expansion. A theory that gained considerable popularity there argues that current employees ("insiders") have the power to make it unprofitable for the firm to hire potential employees ("outsiders") at lower wages (Lindbeck and Snower 1986). Thus the burden of unemployment falls on the outsiders, while the insiders who may be protected by union membership enjoy both the stability of indexed incomes and a high degree of job security. A more general theory of hysteresis or high persistence of unemployment is developed in Blanchard and Sumers 1986, 1987; for a different view, see Gordon 1987. 
8 For an early study that encouraged the former thesis, see Berle and Means 1932; for the latter position, see Stigler 1949 and Nutter 1951. Stigler's judgment was that "competition declined moderately from the Civil war to the end of the nineteenth century, and thereafter increased moderately" ( $p .54$ ). Nutter's estimate of the share of manufacturing output accounted for by monopolistic industries (those with four-firm concentration ratios of 50 and higher) was 33\% for 1895-1904, and Scherer 1980 (p. 68) obtains approximately the same figure for 1963 (the corresponding proportions were $24 \%$ in $1947,30 \%$ in 1954 and $1958,29 \%$ in 1972).

${ }^{9}$ This hypothesis is not an easy one to test but very much worth testing.

${ }^{10}$ In terms of the familiar model AD going back to Hicks 1937, the rise of real balances shifts LM to the right, the rise of real wealth shifts is to the right.

${ }^{11}$ Note that the argument about the depressant effect of a $r$ ise in the real burden of nominal debt and the attendant wealth redistribution relies on the current movement of $P$, and not $p$. A failure of foresight is still required, but only one that occurred earlier, at the time when the debts had been contracted for. The debtors must have failed to anticipate the downturnand decline in $P$, which is easy to explain if these were rare events.

12 Friedman and Schwartz (1963, pp. 49-42) describe the post-Civil War period 1865-1873 as one of deflation in product prices but not money wages, mild $r$ ise in the stock of money, and a high average rate of increases in real income. Zarnowitz and Moore (1986, p. 553) compare some periods of low or negative inflation and relatively high real growth (e.g., 1923-1929) with others of high inflation and lower growth (e.g., 1969-81). When inflationary trends prevail, business expansions tend to be longer but not necessarily stronger (ibid., pp. 525-531).

${ }^{13}$ Survey data for $1959-76$ indicate that forecasts of inflation have been on the average closely related to the most recent observed values of inflation (Zarnowitz 1979).

${ }^{14}$ Baily's own preferred figures correspond to line 2 in Section A of Table 4.

${ }^{15}$ The literature is voluminous. For surveys and references see Jorgenson 1971 ; Clark 1979; Chirinko 1988. See also the estimates and critique of investment equations in Gordon and Veitch 1986.

${ }^{16}$ That this was so looks particularly plausible for the pre-World War I era of the gold standard, when the long-term rate of prices was near zero (which, incidentally, helps explain the shape and relatively good fit of the original Phillips curve for the United Kingdom, see Phillips 1958 and Barro 1987, ch. 16).

17 DeLong and Summers (1986a, pp. 714-719) use a VAR model with the actual/potential output ratio, inflation, and commercial paper rate to argue support their analysis. But the reduced-form evidence from small models of this type is not dependable: adding more variables, for example, can easily change the results. The same argument applies to the VAR model used on the other side of the debate in Taylor 1986a (where only real GNP and inflation are included). 
References

Baily, M. 1978. Stabilization Policy and Private Economic Behavior. Brookings Pap. Econ Act., vol. I, pp. 11-59.

Barro, R.J. 1987. Macroeconomic. New York: Wiley.

Berle, A.A. and G. Means. 1932. The Modern Corporation and Private Property. New York: Macmillan.

Bernanke, B.S. and J.L. Powell. 1986. The Cyclical Behavior of Industrial Labor Markets: A Comparison of the Prewar and Postwar Eras. In: R.J. Gordon, ed., The American Business Cycle: Continuity and Change, pp. 583-621 and 633-637. Chicago: University of Chicago Press for NBER.

Bernanke, B.S. 1981. Bankruptcy, Liquidity, and Recession. Amer. Econ. Rev., vol. 71, pp. 155-159 (May).

Bernanke, B.S. 1983. Nonmonetary Effects of the Financial Crisis in the Propagation of the Great Depression. Amer. Econ. Rev., vol. 73, no. 3, pp. 257-276 (June).

Bils, M. 1985. Real Wages Over the Business Cycle: Evidence From Panel Data. J. Polit. Econ., vol. 93, no. 4, pp. 666-689 (August).

Blanchard, O.J. and L.H. Summers. 1986. Hysteresis and the European Unemployment Problem. In: S. Fischer, ed. NBER Macroeconomics Annual 1986. Cambridge, MA: The MIT Press.

Blanchard, O.J. and L.H. Summers. 1987. Eiscal Increasing Returns, Hysteresis, Real Wages and Unemployment. European Econ. Rev. 31(3): 543-560 (April).

Cagan, P. 1975. Changes in the Recession Behavior of Wholesale Prices in the 1920's and Post-World War II. Explorations in Economic Research, vol. 2, no. 1, pp. 54-104 (Winter).

Cagan P. 1979. Persistent Inflation: Historical and Policy Essays. New York: Columbia University Press.

Carlton, B.W. 1986. The Rigidity of Prices. Amer. Econ. Rev, vol. 76, no. 4, pp. 637-658 (September).

Caskey, J. and S. Fazzari. 1987. Aggregate Demand Contractions with Nominal Debt Commitments: Is Wage Flexibility Stabilizing? Econ. Inquiry. vol, 25, pp. 583-597 (October)..

Chirinko, R.S. 1988. Will 'the' Neoclassical Theory of Investment Please Rise? The General Structure of Investment Models and Their Implications for Tax Policy. In: J.M. Mintz and D.D. Purvis, eds., The Impact of Taxation on Business Investment. 
Clark, P.K. 1979. Investment in the 1970's: Theory, Performance, and Prediction. Brookings Pap. Econ. Act., vol. 1, pp. 73-113.

Creamer, D. 1950. Behavior of Wage Rates during Business Cycles. New York: NBER,

Creamer, D. assisted by M. Bernstein. 1956. Personal Income During Business Cycles. Princeton: Princeton University Press for NBER.

DeLong, J.B. and L.H. Summers, 1986a. The Changing Cyclical Variability of Economic Activity in the United States. In: R.J. Gordon, ed., The American Business Cycle: Continuity and Change, pp. 679-727 and 732-734.

DeLong, J.B. and L.H. Summers. 1986b. Is Increased Price Flexibility Stabilizing? Amer. Econ. Rev., vol. 76, no. 5, pp. 1031-1044 (December).

Douglas, P.H. 1930. Real Wages in the United States. 1890-1926. Boston: Houghton Mifflin.

Driskill, R.A. and S.M. Sheffrin. 1986. Is Price Flexibility Destabilizing? Amer. Econ. Rev., vol. 76, no. 4, pp. 802-807 (September).

Fisher, I. 1933. The Debt-Deflation Theory of Great Depressions. Econometrica, vol. 1, pp. 337-357.

Fischer, S. and F. Modigliani. 1978. Towards an Understanding of the Real Effects and Costs of Inflation. Weltwirtschaftliches Archiv., vol. 114, pp. $810-883$.

Freeman, R.B. 1988. Contraction and Expansion: The Divergency of Private Sector and Public Sector Unionism in the United States. J.Econ. Perspec., vol. 2, no. 2, pp. 63-88 (Spring).

Friedman, M. 1977. Nobel Lecture: Inflation and Unemployment. Journal of Political Economy, vol. 85, no. 3, pp. 451-472 (June).

Friedman, M. and A.J. Schwartz. 1963. A Monetary History of the United States, 1867-1960. Princeton: Princeton University Press for NBER.

Friedman, M. and A.J. Schwartz, 1982. Monetary Trends in the United States and the United Kingdom: Their Relation to Income, Prices and Interest Rates, 1867-1975. Chicago: University of Chicago Press for NBER.

Geary, P.T. and J. Kennan. 1982. The Employment-Real Wage Relationship: An International Study. J. Polit. Econ., vol. 90, no. 5, pp. 854-871 (August).

Gordon, R.J. 1983. A Century of Evidence on Wage and Price Stickiness in the United States, United Kingdom, and Japan. In: J. Tobin, ed. Macroeconomics, Prices, and Quantities. Washington, DC: Brookings Institution, pp. 85-121.

Gordon, R.J. 1987. Productivity, Wages, and Prices Inside and Outside of Manufacturing in the U.S., Japan, and Europe. European Econ., Rev.. 31(3): 685-739 (April). 
Gordon, R.J. and J.M. Veitch. 1986. Fixed Investment in the American Business Cycle, 1919-83. In: R.J. Gordon, ed., The American Business Cycle: Continuity and Change, pp. 267-335 and 352-357. Chicago: University of Chicago Press for NBER.

Grossman, H.I. 1986. Comment. In R.J. Gordon, ed., The Amer. Bus. Cycle: Continuity and Change, pp, 728-731.

Haberler, G. 1988. Wage and Price Rigidities, Supply Restrictions, and the Problem of Stagflation. In T.D. Willett, ed., Political Business Cycles, pp. 145-176. Durham and London: Duke University Press.

Hart, A.G. 1938. Debts and Recovery. New York: Twentieth Century Fund. Hicks, J.R. 1937. Mr. Keynes and the 'Classics': A Suggested Interpretation. Econometrica 5: 147-159.

Jorgenson, D.W. 1971. Econometric Studies of Investment Behavior: A Survey. J. Econ. Lit., vol. 9, no. 4, pp. 1111-1147 (December).

Keynes, J.M. 1936. The General Theory of Employment, Interest, and Money. London: Macmillan.

King, S.R. 1988. Is Increased Price Flexibility Stabilizing? A Comment. Amer. Econ. Rev., vol. 78, no. 1, pp. 267-272 (March).

Lindbeck, A. and D. Snower. 1986. Explanations of Unemployment. Oxford Rev Econ. Pol., vol. 1, no. 2, pp. 34-59.

Long, C.D. 1960. Wages and Earnings in the United States, 1860-1890. New York: NBER.

Makin, J.H. 1982. Anticipated Money, Inflation Uncertainty and Real Economic Activity, Rev. Econ. Statis., vol. 64, no, 1, pp. 126-135 (February).

Minsky, H.P. 1975. John Maynard Keynes. New YorK: Columbia University Press.

Minsky, H.P. 1977. A Theory of Systemic Fragility. In: E.J. Altman and A.W. Sametz, eds., Financial Crises: Institutions and Markets in a Fragile Environment, pp. 138-152. New York: Wiley.

Mishkin, F.S. 1981. The Real Interest Rate: An Empirical Investigation. In: Brunner, K. and A.H. Meltzer, eds. The Costs and Consequences of Inflation. Carnegie-Rochester Confer. Publ. Pol., vol. 15. Amsterdam: North-Holland.

Mitchell, D.J.B. 1980. Unions, Wages, and Inflation. Washington, D.C.: Brookings Institution.

Moore, G.H. 1983. Business Cycles, Inflation and Forecasting. Cambridge, MA: Ballinger Publishing Co. for NBER (second ed.) 
Moore, G.H. and J.P. Cullity. 1983. Trends and Cycles in Productivity, Unit Costs, and Prices: An International Perspective. In: G.H. Moore, Business Cycles, Inflation, and Forecasting, 2nd ed., Cambridge, MA: Ballinger for NBER.

Nutter, G. Warren. 195\%. Extent of Enterprise Monopoly in the United States 1899-1939. Chicago: The University of Chicago Press.

Phelps Brown, E.H., with H.H. Browne. 1968. A Century of Pay. London: Macmillan.

Phillips, A.W. 1981. The Relation Between Unemployment and the Rate of Change of Money Wage Rates in the United Kingdom, 1862-1957. Economica, N.S. 25: 283-299.

Reder, M.W. 1988. The Rise and Fall of Unions: The Public Sector and the Private. J. Econ. Perspec., vol. 2, no. 2, pp. 89-110 (Spring).

Rees, A. 1960. New Measures of Wage-Earner Compensation in Manufacturing 1914-57, New York, NBER.

Rees, A. assisted by D.P. Jacobs. 1961. Real Wages in Manufacturing, 18901914. Princeton: Princeton University Press for NBER.

Rees, A. 1973. The Economics of Work and Pay. New York: Harper \& Row.

Sachs, J. 1980. The Changing Cyclical Behavior of Wages and Prices: 18901976. Amer. Econ. Rev., vol. 70, no. 1, pp. 78-90 (March).

Scherer, F.M. 1980 Industrial Market Structure and Economic Performance, 2nd. ed., Chicago: Rand McNally.

Stigler, George. J. 1949. Five Lectures on Economic Problems. London: Longmans, Green and Co.

Summers, L.H. 1963. The Nonadjustment of Nominal Interest Rates: A Study of the Fisher Effect. In J. Tobin, ed., Macroeconomics, Prices, and

Quantities: Essays in Memory of Arthur Ckun, pp. 63-79, Oxford: Blackwell.

Taylor, J.B. 1979. Staggered Wage Setting in a Macro Model. Amer. Econ. Rev.,, pp. 108-113 (May).

Taylor, J.B. 1980. Aggregate Dynamics and Staggered Contracts. J. Polit. Econ., vol. 88, pp. 1-23 (February).

Taylor, J.B. 1986a. Improvements in Macroeconomic Stability: The Role of Wages and Prices. In R.J. Gordon, ed., The American Business: Continuity and Change, pp. 639-669 and 676-677. Chicago: University of Chicago Press for NBER.

Taylor, J.B. 1986b. Reply. In R. J. Gordon, ed., The American Business Cycle: Continuity and Change, pp. 672-675. Chicago: University of Chicago Press for NBER. 
Tobin, J. 1975. Keynesian Models of Recession and Depression. Amer. Econ. Rev., vol. 65, no. 2, pp. 301-317 (May).

Tobin, J. 1980. Asset Accumulation and Economic Activity: Reflections on Contemporary Macroeconomic Theory. Chicago: University of Chicago Press.

Tsiang, S. 1947. The Variations of Real Wages and Profit Margins in Relation to the Trade Cycle. London: Pitman.

Zarnowitz, V. 1989. Facts and Factors in the Recent Evolution of Business Cycles in the United States. NBER Working Paper no. 2865 (February).

Zarnowitz, V. and G.H. Moore. 1986. Major Changes in Cyclical Behavior. In: R.J. Gordon, ed., The American Business Cycle Today, pp. 519-572 and 579582. Chicago: University of Chicago Press for NBER.

Zarnowitz, V. and L.A. Lambros. 1987. Consensus and Uncertainty in Econimc Prediction. J. Polit. Econ., vol. 95, no. 3, pp. 591-621 (June). 